\title{
PENGARUH PENGGUNAAN MEDIA SOFTWARE SIMULASI ELECTRICAL CONTROLTECHNIQUES SIMULATOR TERHADAP HASIL BELAJAR SISWA PADA MATA PELAJARAN INSTALASI MOTOR LISTRIK PADA KOMPETENSI DASAR PENGASUTAN MOTOR LISTRIK
}

\author{
Dinan Roy Sandi Siburian ${ }^{1}$, Arwadi Sinuraya ${ }^{2}$ \\ Fakultas Teknik, Universitas Negeri Medan \\ dinanroy458@gmail.com
}

\begin{abstract}
This study aims to find out if the use of Electrical Control Techniques Simulator (EKTS) Simulation Software as a learning medium in electrical motor installation subjects can improve students' learning outcomes in Grade XI TITL At SMK Negeri 1 Percut Sei Tuan.. Abstract must reflect the overall substance of the article content and be able to help readers determine its relevance to their interests and decide whether to read the document in its entirety. The research was conducted at SMKN 1 Percut Sei Tuan which is located at Jalan Kolam No 3 Kenangan Baru, Kec Percut Seituan, Deli Serdang Regency and the research time will be conducted in the odd semester of the 2019-2020 School Year. The object of this research is the learning media in the form of software electrical control techniquessimulator subjects electrical motor installation. The subjects in this study were students of grade XI Electrical Installation Engineering at SMKN 1Percut Sei Tuan, with a sample of Class XI TITL 2 research. The results showed that in general, the learning media of Electrical Control Techniques Simulator simulation software has a significant influence on students' learning outcomes. The results of learning the installation of electric motors students who are taught using the learning media simulation software Electrical Control Techniques Simulator can be higher because through this learning media students can more easily understand a series of installations of motor linking through the animation of the series of electric motors displayed by the simulation software media Electrical Control Techniques Simulator Where the average learning outcome of students who are taught with the Learning Media simulation software Electrical Control Techniques Simulator obtained a score of 8.01 with the highest score being 9.0 and the lowest score being 7.0 compared to students taught with learning media The Whiteboard obtained an average score of 6.544 with the highest score being 7.5 and the lowest score being 5.0.
\end{abstract}

Key Words: Electrical control techniques, motor instalation

\begin{abstract}
Abstrak
Penelitian ini bertujuan untuk mengetahui apakah penggunaan Software Simulasi Electrical Control Techniques Simulator (EKTS) sebagai media pembelajaran pada mata pelajaran instalsi motor listrik dapat meningkatkan hasil belajar siswa di Kelas XI TITL Di SMK Negeri 1 Percut Sei Tuan. Penelitian dilaksanakan di SMKN 1 Percut Sei Tuan yang beralamat di Jalan Kolam No 3 Kenangan Baru, Kec. Percut Sei Tuan, Kab. Deli Serdang dan waktu penelitian dilaksanakan pada semester ganjil T.A. 2019-2020. Objek penelitian ini adalah media pembelajaran berupa Software electrical control techniquessimulator mata pelajaran instalasi motor listrik. Subjek dalam penelitian ini adalah siswa kelas XI Teknik Instalasi Tenaga Listrik di SMKN 1 Percut Sei Tuan, dengan sampel penelitian Kelas XI TITL 2. Hasil penelitian menunjukkan bahwa secara umum Media pembelajaran software simulasi Electrical Control Techniques Simulator memberikan pengaruh yang signifikan terhadap hasil belajar siswa. Hasil belajar instalasi motor listrik siswa yang diajar dengan menggunakan Media pembelajaran software simulasi Electrical Control Techniques Simulator dapat lebih tinggi karena melalui Media pembelajaran ini siswa dapat lebih mudah untuk memahami sebuah rangkaian instalasi pengasutan motor melalui animasi rangkaian motor listrik yang ditampilkan oleh media software simulasi Electrical Control Techniques Simulator Dimana rata-rata hasil belajar siswa yang diajar dengan Media pembelajaran software simulasi Electrical Control Techniques Simulator memperoleh nilai 8,01 dengan nilai tertinggi adalah 9,0 dan nilai terendah adalah 7,0 dibandingkan dengan siswa yang diajar dengan media pembelajaran Papan Tulis memperoleh nilai rata-rata 6,544 dengan nilai tertinggi adalah 7,5 dan nilai terendah adalah 5,0.
\end{abstract}

Kata Kunci: Electrical control techniques, instalasi motor 


\section{PENDAHULUAN}

Pendahuluan antara lain berisi latar belakang masalah, kesenjangan antara yang diidealkan dan yang senyatanya, didukung oleh teori dan penelitian mutakhir yang relevan tentang masalah, dan nilai baru penelitian yang merupakan inovasi. Bagian ini ditulis sebanyak maksimum $20 \%$ dari badan artikel.

Naskah artikel merupakan karya asli berupa hasil penelitian atau hasil kajian dalam bidang pendidikan vokasi kelistrikan yang belum pernah diterbitkan di dalam maupun di luar negeri. Tidak ada subjudul dalam isi artikel. Naskah ditulis dalam bahasa Indonesia minimal 8 halaman maksimal 10 halaman.

Naskah artikel yang diterima akan ditelaah oleh mitra bestari sesuai kepakarannya, dan penulis harus bersedia melakukan perbaikan atas masukan mitra bestari dan atau penyunting. Program komputer (software) yang digunakan untuk pembuatan maupun editing naskah, atau hal lain yang berkaitan dengan kekayaan intelektual, berikut konsekuensi hukumnya, menjadi tanggung jawab penulis naskah.

\section{METODE}

Penelitian pengembangan Media EKTS Instalasi Motor Listrik ini disebut juga Research and Development (R\& D). Tujuan dari penelitian pengembangan ini adalah untuk mengembangkan media EKTS pada mata pelajaran Instalasi Motor Listrik, dan menghasilkan EKTS sebagai media pembelajaran praktik Instalasi Motor Listrik XI Teknik Instalasi Tenaga Listrik di SMKN 1 Percut Sei Tuan. Model penelitian disesuaikan dengan Thiagarajan, Semmel, dan Semmel (1974) dalam Trianto (2015) yaitu pengembangan Four-D Models. Model Four-D terdiri dari 4 tahap pengembangan yaitu: define, design, develop, dan desseminate atau diadaptasikan menjadi model 4-P yaitu (1) Pendefinisian (Define) yang meliputi tahap analisis ujung depan, analisis siswa, analisis tugas, analisis konsep, dan perumusan tujuan pembelajaran. (2) Perancangan (Design) yang meliputi tahap penyusunan tes acuan patokan, tahap pemilihan media, pemilihan format. (3) Pengembangan meliputi validasi perangkat oleh para pakar diikuti dengan revisi, simulasi, uji coba terbatas dengan siswa sesungguhnya. (4) Tahap penyebaran (Disseminate) merupakan tahap penggunaan perangkat yang telah dikembangkan pada skala yang lebih luas, misalnya sekolah lain, kelas lain. Tahap penyebaran (Disseminate) ini dilakukan terbatas dengan memberikan hasil produk pengembangan ke sekolah.

\section{HASIL DAN PEMBAHASAN}

Penelitian ini merupakan penelitian eksperimen yang melibatkan dua kelas yang diberi perlakuan yang berbeda, yaitu kelas eksperimen menggunakan media pembelajaran software simulasi Electrical Control Techniques Simulator dan kelas kontrol menggunakan media pembelajaran papan tulis. Diakhir penelitian pada kedua kelas diberikan instrument tes berupa test pilihan berganda yang berjumlah 20 soal untuk mengetahui hasil belajar siswa setelah melalui proses pembelajaran

\section{Hasil}

1. Hasil belajar siswa pada kelas eksperimen

Berdasarkan test hasil belajar yang diberikan maka data hasil belajar siswa kelas eksperimen diperoleh nilai tertinggi 9 dan nilai terendah 7,0 dengan nilai rata-rata 8,01 dan standart deviasi (sd) $=0,602205$. Dengan menggunakan aturan Sturges (Sudjana, 2005:47) diperoleh banyak kelas 6, panjang kelas 0,4 dan dimulai dengan ujung bawah kelas pertama 7,0 maka daftar distribusi frekuensi mengenai hasil belajar siswa yang menggunakan media pembelajaran software simulasi Electrical Control Techniques Simulator dapat dilihat pada tabel berikut.

Tabel 1. Distribusi frekuensi hasil belajar siswa yang diajar dengan media pembelajaran software simulasi Electrical Control Techniques Simulator

\begin{tabular}{|c|c|c|}
\hline Interval kelas & $\begin{array}{c}\text { F } \\
\text { ABSOLUT }\end{array}$ & $\begin{array}{c}\text { Frelatif } \\
(\%)\end{array}$ \\
\hline $7,0-7,3$ & 3 & 9,375 \\
\hline $7,4-7,7$ & 9 & 28,125 \\
\hline $7,8-8,1$ & 8 & 25 \\
\hline
\end{tabular}




\begin{tabular}{|c|c|c|}
\hline $8,2-8,5$ & 8 & 25 \\
\hline $8,6-8,9$ & 0 & 0 \\
\hline $9,0-9,3$ & 4 & 12,5 \\
\hline Jumlah & 32 & 100 \\
\hline
\end{tabular}

Dari distribusi frekuensi hasil belajar Pengasutan Motor Listrik pada mata pelajaran Instasi Motor Listrik dapatdigambarkan histogram distribusi pada gambar 1 dibawah ini.

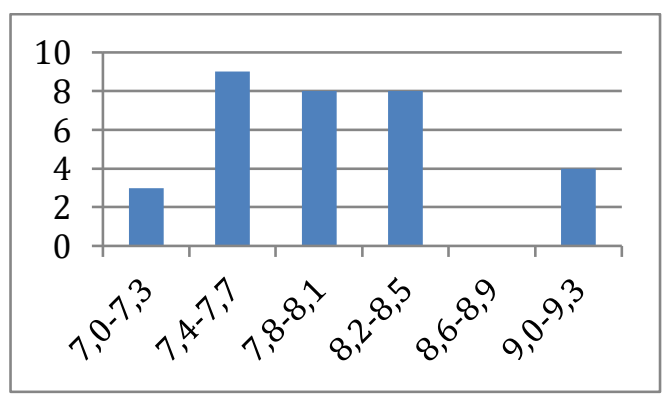

Gambar 1 Histogram Distribusi Frekuensi Data Hasil Belajar Pengasutan Motor Listrik Pada Mata Pelajaran Instalasi Motor Listrik

\section{Hasil Belajar Siswa Pada Kelas Kontrol}

Berdasarkan test hasil belajar yang diberikan maka data hasil belajar siswa kelas kontrol diperoleh nilai tertinggi 7,5 dan nilai terendah 5,0 dengan nilai rata-rata 6,544 dan standart deviasi $(\mathrm{sd})=0,680777$.

Dengan menggunakan aturan Sturges (Sudjana, 2005:47) diperoleh banyak kelas 6, panjang kelas 0,5 dan dimulai dengan ujung bawah kelas pertama 5,0 maka daftar distribusi frekuensi mengenai hasil belajar siswa yang menggunakan media pembelajaran software simulasi Electrical Control Techniques Simulator dapat kita lihat pada tabel berikut.

Tabel 2. Distribusi frekuensi hasil belajar siswa yang diajar dengan media software simulasi Electrical Control Techniques Simulator

\begin{tabular}{|c|c|c|}
\hline Interval kelas & $\begin{array}{c}\mathrm{F} \\
\text { ABSOLUT }\end{array}$ & $\begin{array}{c}\text { Frelatif } \\
(\%)\end{array}$ \\
\hline $5,0-5,4$ & 1 & 3,125 \\
\hline $5,5-5,9$ & 6 & 18,75 \\
\hline $6,0-6,4$ & 6 & 18,75 \\
\hline $6,5-6,9$ & 8 & 25 \\
\hline $7,0-7,4$ & 8 & 25 \\
\hline $7,5-7,9$ & 3 & 9,375 \\
\hline Jumlah & 32 & 3,125 \\
\hline
\end{tabular}

Dari distribusi frekuensi hasil belajar Pengasutan Motor Listrik dalam mata pelajaran Instalasi Motor Listrik pada kelas Kontrol (media konvensional) dapat digambarkan histogram distribusi pada gambar 2 dibawah ini.

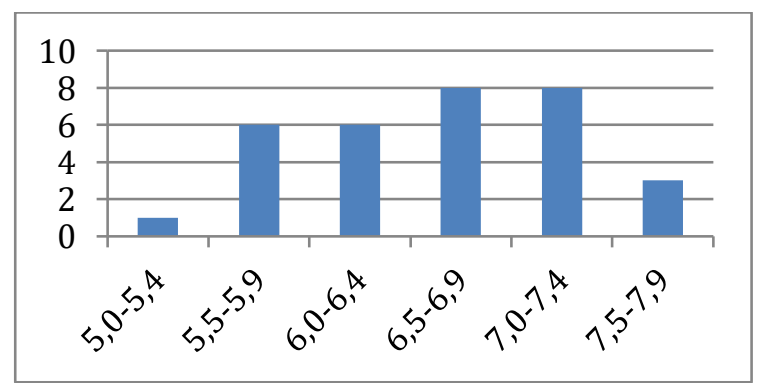

Gambar 2 Histogram Distribusi Frekuensi Data Hasil Belajar Pengasutan Motor Listrik dalam Instalasi Motor Listrik 


\section{Pembahasan}

1. Uji Normalitas Data

Untuk menguji normalitas data digunakan uji Liliefors yang bertujuan untuk mengetahui apakah penyebaran data tes hasil belajar siswa memiliki sebaran data yang berdistribusi normal atau tidak. Sampel berdistribusi normal jika dipenuhi $\mathrm{L}_{0}<\mathrm{L}_{\text {tabel }}$ pada taraf signifikan $\alpha=5 \%$.

Berdasarkan lampiran 13 uji normalitas data hasil belajar siswa kelas eksperimen diperoleh $\mathrm{L}_{0}(-$ $0,050)<\mathrm{L}_{\text {tabel }}(0,156)$. Berdasarkan lampiran 13 uji normalitas data hasil belajar siswa kelas kontrol diperoleh $\mathrm{L}_{0}(-0,080)<\mathrm{L}_{\text {tabel }}(0,156)$.

Dengan demikian dapat disimpulkan distribusi data hasil belajar siswa dengan media pembelajaran software simulasi Electrical Control Techniques Simulator berdistribusi normal.

2. Uji Homogenitas

Untuk menguji homogenitas dilakukan dengan menggunakan uji $\mathrm{F}$ untuk mengetahui apakah kelompok sampel berasal dari populasi yang homogen atau tidak. Populasi yang homogen jika $F_{\text {hitung }}<$ $\mathrm{F}_{\text {tabel. }}$. Dengan derajat kebebasan pembilang $=\left(\mathrm{n}_{1}-1\right)$ dan derajat kebebasan penyebut $=\left(\mathrm{n}_{2}-1\right)$ dengan tarafnyata $\alpha=5 \%$. Perhitungan uji homogenitas dapat dilihat pada tabel berikut.

Tabel 3. Uji Homogenitas Hasil Belajar Siswa

\begin{tabular}{|c|c|c|}
\hline & Kelas Eksperimen & Kelas Kontrol \\
\hline Banyak siswa & 32 & 32 \\
\hline Varians & 0,362 & 0,463 \\
\hline$F_{\text {hitung }}$ & \multicolumn{2}{|c|}{1,279} \\
\hline$F_{\text {tabel }}$ & \multicolumn{2}{|c|}{1,822} \\
\hline Status & Homogen \\
\hline
\end{tabular}

Diperoleh $\mathrm{F}_{\text {tabel }}=1,822$. Dengan demikian dapat dilihat bahwa $\mathrm{F}_{\text {hitung }}<\mathrm{F}_{\text {tabel }}$ yakni 1,279 $<1,822$. Hal ini berarti kedua kelompok sampel (kelas eksperimen dan kelas kontrol) berasal dari populasi yang homogen.

A. Pengujian Hipotesis

Pengujian hipotesis dihitung dengan menggunakan uji t. Karena data hasil belajar kedua kelas berdistribusi normal dan homogen, maka rumus yang digunakan sebagai berikut :

Hipotesis yang akan diuji adalah :

$$
t_{\text {hitung }}=\frac{X 1-X 2}{\sqrt[s]{\frac{1}{n 1}+\frac{1}{n 2}}}, \text { dengan } S^{2}=\frac{(n 1-1) S_{1}^{2}+(n 2-1) S_{2}^{2}}{n 1+n 2-2}
$$

Ho : thitung $\leq$ ttabel

Ha : thitung $>$ ttabel

Data untuk uji hipotesis ini dapat dilihat pada tabel berikut.

Tabel 4. Data uji hipotesis

\begin{tabular}{|c|c|c|c|c|}
\hline \multicolumn{2}{|c|}{ Rata-rata Hasil Belajar Siswa } & \multirow[b]{2}{*}{$t_{\text {hitung }}$} & \multirow[b]{2}{*}{$\mathrm{t}_{\text {tabel }}$} & \multirow[b]{2}{*}{ Kesimpulan } \\
\hline $\begin{array}{c}\text { Kelas } \\
\text { Eksperimen }\end{array}$ & Kelas Kontrol & & & \\
\hline 8,01 & 6,544 & 9,13395 & 1,67 & $\begin{array}{c}\mathrm{H}_{0} \text { ditolak dan } \\
\mathrm{H}_{\mathrm{a}} \text { diterima }\end{array}$ \\
\hline
\end{tabular}

Dengan membandingkan nilai $t_{\text {hitung }}$ dengan nilai $t_{\text {tabel }}$ diperoleh $t_{\text {hitung }}>t_{\text {tabel }}$ yaitu 9,13395 $>1,67$. Dengan demikian $\mathrm{H}_{0}$ ditolak dan $\mathrm{H}_{\mathrm{a}}$ diterima maka hasil belajar siswa pada mata pelajaran instalasi motor listrik yang diajar dengan menggunakan media pembelajaran software simulasi Electrical Control Techniques Simulator di kelas XI Teknik Instalasi Tenaga Listrik (TITL 2) SMK N 1 Percut Sei Tuan lebih tinggi dari pada hasil belajar siswa pada mata pelajaran Instalasi Motor Listrik yang diajar tidak menggunakan media pembelajaran software simulasi Electrical Control Techniques 
Simulator ( Menggunakan Media Papan Tulis ) di kelas XI Teknik Instalasi Tenaga Listrik (TITL 1) SMK N 1 Percut Sei Tuan.

Berdasarkan hasil analisis data yang telah dilakukan dalam penelitian ini maka dapat dikemukakan temuan penelitian sebagai berikut : Hasil belajar siswa pada mata pelajaran Instalasi Motor Listrik yang diajar dengan menggunakan Media pembelajaran software simulasi Electrical Control Techniques Simulator di kelas XI TITL 2 SMK N 1 Percut Sei Tuan lebih tinggi daripada hasil belajar siswa pada mata pelajaran Instalasi Motor Listrik yang diajar dengan menggunakan Media Papan Tulis di kelas XI TITL 1 SMK N 1 Percut Sei Tuan. Dimana diperoleh $t_{\text {hitung }}=9,13395$ sedangkan $t_{\text {tabel }}=1,67$. Maka $t_{\text {hitung }}>t_{\text {tabel }}=9,13395>1,67$ yang berarti $\mathrm{H}_{0}$ ditolak dan $\mathrm{H}_{\mathrm{a}}$ diterima.

\section{SIMPULAN}

Berdasarkan hasil penelitian yang diperoleh dari analisis data diperoleh beberapa kesimpulan, yaitu : Hasil belajar siswa pada mata pelajaran Instalasi Motor Listrik yang diajar dengan menggunakan media pembelajaran Electrical control techniques simulator di kelas XI TITL 2 SMK Negeri 1 Percut Sei Tuan memperoleh nilai rata - rata 8,01 dengan nilai tertinggi 9 dan nilai terendah 7 lebih tinggi jika dibandinkan dengan hasil belajar siswa pada mata pelajaran Instalasi Motor Listrik yang diajar dengan menggunakan media Papan Tulis di kelas XI TITL 1 SMK Negeri 1 Percut Sei Tuan yang memperoleh nilai rata - rata 6,544 dengan nilai tertinggi 7,5 dan nilai terendah 5 . Hasil belajar siswa yang diajar dengan Media pembelajaran software simulasi Electrical Control Techniques Simulator mempunyai nilai rata-rata sebesar 8,01 sedangkan siswa yang diajar dengan media pembelajaran papan tulis mempunyai nilai selisih rata-rata sebesar 6,544

\section{DAFTAR PUSTAKA}

Arikunto, Suharsimi. (2006). Prosedur Penelitian Suatu Tindakan Praktek. Jakarta: Rineka Cipta (2009). Dasar-dasar Evaluasi Pendidkan. Jakarta: Bumi Aksara. . (2013). Dasar-dasar Evaluasi Pendidkan. Jakarta: Bumi Aksara.

Ariyanto Yana, Pengaruh Penggunaan Media Electrical control techniques simulator terhadap hasil belajar siswa pada mata diklat motor listrik 3 phasa, Skripsi, tidak di terbitkan, Fakultas Teknik Universitas Negeri Yogyakarta

Azhar Arsyad. (2002). Media Pembelajaran. Jakarta: PT. Raja Grafindo Persada

Corey (Syaiful Sagala, 2011: 61)

Depdiknas. (2006). Peraturan Menteri Pendidikan Nasional Nomor 22 Tahun 2006. Tentang Standar Isi.

Dimyati dan Mudjiono. (2009). Belajar dan Pembelajaran. Jakarta: PT. Rineka Cipta.

Fakultas Teknik. (2016). Buku Pedoman Penulisan Skripsi. Medan: FT Unimed.

Kementrian Pendidikan dan Kebudayaan Republik Indonesia.(2014). Instalasi Motor Listrik Semester 3. Jakarta.

Purwanto. 2014. Evaluasi Hasil Belajar. Yogyakarta: Pustaka Pelajar.

Rifa'i. (2011). Psikologi Pendidikan. Semarang: UNNES Press.

Rusman. (2013). Model-model pembelajaran. Jakarta: PT. Raja Grafindo Persada. 